\author{
Saška Štumberger \\ Filozofska fakulteta Univerze v Ljubljani
}

\title{
Slovaropisna obravnava novejše leksike
}

V članku so predstavljene slovaropisne obravnave novejše leksike v slovenskih in nemških splošnih slovarjih in v posebnih slovarjih novejše leksike. V splošnih slovarjih je novejša leksika obravnavana brez posebnih časovnih kvalifikatorjev ali označena s posebnimi časovnimi kvalifikatorji za različne vrste novejše leksike. Posebni slovarji novejše leksike so časovno omejeni na krajše obdobje, nastajajo pa kot dopolnilo obstoječih slovarjev ali bolj natančni opisi leksike določenega obdobja. V tem primeru posebni slovarji novejše leksike v primerjavi s splošnimi slovarji vsebujejo dodatne informacije o nastanku novejših enot, pojavitvah v različnih gradivnih virih in variantnosti rabe.

The article presents the way that new lexis is handled in Slovenian and German general and specialized dictionaries of new lexis. In general dictionaries new lexis has no special time qualifiers and is not labelled with any special time qualifiers for different kinds of new lexis. Specialized dictionaries of new lexis are limited in time to a short period. They are designed as a supplement to the existing dictionaries or a more thorough description of lexis of a certain period. In this case, in comparison to general dictionaries, specialized dictionaries contain additional information about the emergence of new words, appearance in different material sources and variants of use.

\section{Opredelitve novejše leksike ${ }^{1}$}

Novejšo leksiko lahko opredelimo po naslednjih kriterijih: razmerje med vsebino in izrazom, časovni vidik in razširjenost leksema.

Razmerje med vsebino in izrazom se nanaša na $» 1$. znak v njegovi izrazni in vsebinski celoti ali 2. samo na eno od obeh strani, namreč na vsebinsko stran (pomen)« (Kinne 1996: 343). V slovenskih člankih, ki so nastali ob zbiranju gradiva na Inštitutu za slovenski jezik Frana Ramovša, ločijo naslednje tipe novejše leksike: »(1) beseda ${ }^{2}$ je (tvorbeno) nova, torej nov izraz za novo predmetnost /.../, (2) lahko

${ }^{1}$ Prispevek je predelano in aktualizirano poglavje doktorske disertacije Pojmovni svet in struktura novejšse slovenske leksike (2011).

${ }^{2} \mathrm{Na}$ izrazni ravni avtorice pišejo samo o besedah. 
je novoopomenjen izraz, ki predstavlja a) širjenje pomenja ${ }^{3}$ besede, ki je zaradi splošne uveljavljenosti in uzaveščenosti že predstavljena v SSKJ (miška (rač.) /.../), b) širjenje pomenja besede (tudi v smislu pomenske specifikacije $v$ jeziku že obstoječe besede s širšim pomenskim obsegom), ki ni bila sprejeta v SSKJ (npr. /.../ klepetalnica)« (Gložančev, Kostanjevec 2006: 91). Podobno lahko skoraj pet desetletij prej preberemo tudi pri M. Popoviću (1967: 234): »Kar se tiče značaja neologizmov, moramo razlikovati neologizme - besede in neologizme po pomenu. Prvi so nove besede, drugi so novi pomeni že prej znanih besed.«

Izhodišče pri odločanju o tem, ali leksem spada med novejšo leksiko ali ne, je čas, ki je pretekel od nastanka iz lastnega jezika ali od prevzemanja iz tujega jezika. Odgovor na vprašanje o tem, koliko let mora biti leksem v jeziku, da je še del novejše leksike, je odvisen od govorcev jezika oz. od generacije, ki ji govorci pripadajo: »za eno generacijo je beseda nekaj povsem običajnega, nekaj, kar je vedno obstajalo, za drugo /.../ nekaj povsem novega« (Muhvić-Dimanovski 2005: 61). O novejši leksiki lahko govorimo tudi s stališča slovarjev novejše leksike, ki se »ponavadi omejujejo na časovno zelo strogo definirana obdobja« (prav tam: 62). Ker je čas nastanka novejšega leksema relativna kategorija, ki je odvisna od govorca ali avtorja slovarja novejše leksike, je definicijo smiselno zasnovati širše: »Neologizme obravnavam kot lekseme, katerih čas nastanka je znan in ki jih je večina ljudi jezikovne skupnosti v tem času sicer sprejela, jih pa še vedno dojema kot nove« (Schippan 2002: 244).

Vprašanje razširjenosti novejše leksike zajema dve področji - razmerje novejše leksike do strokovne in neknjižne leksike in razmerje do priložnostnih/enkratnih tvorb (okazionalizmov). Prvo razmerje zajema sprejemanje novejše leksike iz drugih socialnih in funkcijskih zvrsti, kar je pogosto povezano z razširitvijo denotata na področja vsakdanjega življenja. $\mathrm{V}$ tem primeru prihaja do premika »celotne besede oziroma besede v osnovnem pomenu iz samo strokovne rabe. Da se to zgodi, je verjetno treba iskati vzrok v aktualizaciji poimenovanega in s tem tudi v povečani povednosti izraza« (Vidovič Muha 1972: 47). Razmerje med novejšo leksiko in priložnostnimi besedami zajema ločevanje med leksemom in "priložnostno besedo«, ki »se sem ter tja pojavi, ni pa podružbljena, ker se nekako sama poda iz določenega govornega ali besedilnega položaja« (Toporišič 1992: 222). V nemški literaturi za priložnostne besede rabijo termin okazionalizem, za uvrstitev med lekseme pa so potrebni »ustaljenost, sprejetje, leksikalizacija in s tem integracija«, poleg tega pa po M. Kinneju za okazionalizem ne obstaja »splošna komunikativna komunikacijska potreba« (Kinne 1996: 347).

${ }^{3}$ Termin pomenje je v slovensko leksikologijo uvedla A. Vidovič Muha, in sicer je pomenje »izraz za dva ali več pomenov istega leksema in ustreza pojmu semantem « (2000: 19, op. 14). Pomenje je torej »skupek predvidljivo povezanih pomenov, ki pripadajo istemu izrazu (označevalcu); večpomenskost (lastnost pomenja) je določena s povezanostjo pomenov, s tem se tudi - rečeno zelo posplošeno - loči od enakoizraznosti (homonimije)« (prav tam: 52). 


\section{Novejša leksika v slovarjih}

Slovaropisna obravnava zajema dve področji: obravnavo novejše leksike v splošnih slovarjih in posebne slovarje novejše leksike. Novejša leksika gre najprej skozi predslovarsko fazo, »tj. stadij, v katerem (leksemi, op. S. Š.) še niso sprejeti do te mere, da bi jih uvrstili v slovar« (Muhvić-Dimanovski 2005: 77). Čas od nastanka novega leksema do njegovega sprejetja $\mathrm{v}$ slovar in njegova obravnava v slovarju se razlikuje, odvisna je od slovaropisne tradicije in zasnove slovarja. Če primerjamo različne nemške slovarje srednjega obsega - npr. Dudnove in Wahrigove -, ugotovimo, da novejšo leksiko sprejemajo različno hitro. Primerjava števila gesel na črki H in T je pokazala, da ima Wahrigov slovar iz leta 1986 v primerjavi z izdajo iz leta 1980326 novih gesel, medtem ko je v Dudnovi izdaji iz leta 1989 v primerjavi z 1983 novih gesel skoraj trikrat manj - 112 (povzeto po Kirkness 2001: 113).

Raziskovanje novejše leksike v splošnih slovarjih zajema tudi področje označevanja novejše leksike. V novih izdajah nemških splošnih slovarjev (npr. DUDEN. Deutsches Universalwörterbuch $A-Z, 1997)$ opazimo, »da velike nemške založbe vedno znova delajo reklamo s tem, da naj bi najnovejša izdaja vsebovala na tisoče novih besed. Vendar pa te besede težko najdemo, ker niso označene kot nove. Zavest o pomembnosti reklame je torej pri založbah že prisotna in se tudi izkorišča. Kljub temu pa doslej še ni prišlo do diferencirane obravnave nemških neologizmov« (Gstöttner 2003: 14).

Zadnja trditev drži le deloma, kajti avtorica pozablja na vzhodnonemški Slovar sodobnega nemškega jezika (Wörterbuch der deutschen Gegenwartsprache), ki že v 50. letih 20. stoletja prinaša natančne opredelitve in gradivo novejše leksike po letu 1945.

\subsection{Novejša leksika v nemških slovarjih}

Predstavitev nemških slovarjev zajema predstavitev splošnih slovarjev in posebnih slovarjev novejše leksike, začenjam pa jo s Slovarjem sodobnega nemškega jezika. ${ }^{4}$ To je po mojem poznavanju tematike edini splošni slovar s posebnimi časovnimi kvalifikatorji za novejšo leksiko: Neuwort (nova beseda; »besede, ki so v zadnjih desetletjih, posebno od 1945, v nemškem jeziku nastale na novo /.../« (npr. Automation - avtomatizacija, campen - kampirati), Neuprägung (skovanka); »besede in stalne besedne zveze, ki so na novo nastale iz že obstoječih besed /.../« (npr. Atomenergie - jedrska energija, bombengeschädigt - zbombardiran) in Neubedeutung (novopomenka; »že obstoječa beseda je dobila nov pomen«) (Klappenbach, Steinitz

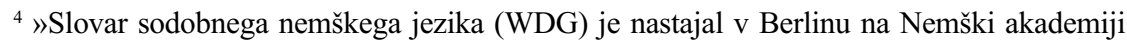
znanosti (od oktobra 1972: Akademija znanosti Nemške demokratične republike) od leta 1952 do 1977. WDG obsega več kot 4500 strani in vsebuje 60.000 oziroma $z$ dodatkom zloženk 90.000 gesel« (Kurzinformation zum WDG, http://www.dwds.de/woerterbuch/1_1, 16. 6. 2007). 
1967: 14. poglavje B. Označevanje časovne pripadnosti - B. Die Kennzeichnung der zeitlichen Zuordnung).

Za razumevanje kriterija splošne razširjenosti kot enega izmed kriterijev za sprejetje novejšega leksema v slovar je pomembno naslednje pojasnilo: »Pri /.../ prikazanih časovnih oznakah je povsem možno, da se je kakšna beseda, ki je označena kot nova beseda, skovanka ali novopomenka, pojavila že prej in bila izpričana (tako npr. Arbeitsnorm - delovna norma). Vendar pa količina pojavitev in odločilna moč splošne rabe pripadata najnovejšemu času in s tem upravičujeta enega od zgoraj navedenih časovnih kvalifikatorjev« (prav tam: 14).

Kot primer rabe časovnih oznak navajam leksem brigada, ki je v obravnavanem slovarju iz Nemške demokratične republike poleg osnovnega pomena vojaške enote dobil dodaten pomen 'delovne skupine', ki ima v slovarju oznako novopomenka. ${ }^{5}$ V 50. letih 20. stoletja je torej (Vzhodna) Nemčija že imela slovar, ki je v svoji zasnovi upošteval tudi časovne oznake. Ta slovar sodobnega nemškega jezika je s svojimi rešitvami sicer vplival na kasnejši razvoj leksikografije, vendar pa v splošnih (zahodno)nemških slovarjih s posebnimi časovnimi oznakami za novejšo leksiko niso nadaljevali (prim. Kinne 1996: 329).

Poleg označevanja novejše leksike v splošnih slovarjih v nemškem slovaropisju poznajo tudi posebne slovarje novejše leksike. V to skupino uvrščamo slovar Neuer Wortschatz: Neologismen der 90er Jahre im Deutschen (Novo besedišče: neologizmi 90. let v nemščini) z natančnim opisom 790 ustaljenih novih besed ${ }^{6}$ in novih pomenov. Zajete so slovarske enote, ki so nastale v 90. letih 20. stoletja. Slovar je izšel leta 2004, že ob izidu pa so načrtovali tudi spletno verzijo, ki je bila prosto dostopna. Danes je stran dopolnjena in premaknjena (http://www.owid.de/docs/neo/wortartikel. jsp, 24. 3. 2015), tako da se razlikuje od natisnjene verzije slovarja.

Nemški slovar neologizmov je primer slovarja, kot ga v slovenskem slovaropisju ne poznamo, kajti geselski članki se razlikujejo od geselskih člankov v splošnih slovarjih. Primerjava zgradbe gesla notebook v Dudnu (1997) in v slovarju neologizmov je pokazala, da je geselski članek v slovarju neologizmov v primerjavi z Dudnovim veliko obsežnejši in da $\mathrm{v}$ primerjavi z Dudnom ponuja še naslednje podatke: čas nastanka leksema, posebnosti besedotvorja; pomen in raba: primeri iz gradiva - korpusa, vrednotenje, pomensko podobni izrazi (sinonimi), tipična raba itd. Na področju slovnice slovar ponuja še slovnične podatke z variantami zapisov, ki jih kaže korpus, in besedotvorno produktivnost ter dodatne informacije $\mathrm{z}$ enciklopedičnimi podatki in podatki o obravnavi gesla $\mathrm{v}$ različnih nemških slovarjih.

${ }^{5}$ Gradivo je bilo 1. 7. 2008 zbrano po spletnem viru http://www.dwds.de/. Kasneje so $\mathrm{v}$ spletni predstavitvi slovarja kvalifikator novopomenka pri geslih izbrisali, tako da je danes spletna različica drugačna od natisnjene (Štumberger 2014: 2, op. 3).

${ }^{6}$ Slovar se pri definiciji termina neologizem omeji na izrazno besedo. 


\subsection{Novejša leksika v slovenskih slovarjih}

Obravnava novejše leksike v slovenskih slovarjih zajema obravnavo in označevanje novejše leksike v splošnih slovarjih (Slovar slovenskega knjižnega jezika, Slovar Slovenskega pravopisa in Slovar slovenskega knjižnega jezika; druga, dopolnjena in deloma prenovljena izdaja), predstavitev Slovarja novejšega besedja slovenskega jezika in novejše leksike na spletnem portalu www.slovenscina.eu.

\subsubsection{Slovar slovenskega knjižnega jezika (SSKJ)}

Slovar slovenskega knjižnega jezika je izhajal od 1970 do 1991, v njem pa je »zajet besedni zaklad (besede, zveze) in prikazana njegova raba, kakor se kaže v sodobnem slovenskem knjižnem jeziku, to je v obdobju od začetka tega stoletja do 1969 oziroma do leta izida posamezne knjige« $(\S 1)$.

Slovarsko gradivo zanj je bilo zbrano klasično - z izpisovanjem, in sicer s kombinacijo paberkovalne metode, metode gostih, popolnih in problemskih izpisov ( 12), ${ }^{7}$ izpisi pa so bili narejeni $»$ iz leposlovnih del, revij, časopisov, poljudnoznanstvenih del in šolskih knjig. Zelo redke so besede, za katere ni izpisov. Gradivo zanje je bilo prevzeto iz Pleteršnikovega slovarja ali iz Slovenskega pravopisa, včasih pa tudi iz listkov s podatki, ki so jih po svojem poznanju zapisali uredniki« (§ 11).

V poskusnem snopiču je bil predviden tudi poseben kvalifikator za novejšo leksiko - neologizem - z razlago »nova, neustaljena raba« (Bajec idr. 1964: 8), ki pa je bil po odzivu strokovne javnosti opuščen. V odzivu na objavo poskusnega snopiča je B. Pogorelec (1963/64) v zvezi s kvalifikatorjem neologizem opozorila na to, da »se je treba vprašati, glede na kaj je ta beseda nova. Zdi se nam, da bi bilo potrebno imenovati neologizme besede, ki jih jezik še čuti kot tuje, nenavadne, ki pa še niso docela prodrle. Morda bi bil boljši kvalifikator novejše ali kaj podobnega. Preden bo slovar izšel, bo takle neologizem, kolikor se bo prijel, že zdavnaj ustaljen in bo kvalifikator stilne plasti zgrešil svoj namen « (prav tam: 236).

S kvalifikatorjem neol. so bili označeni naslednji primeri (Bajec idr. 1964): delati na to (neol. na tem), da bi strmoglavil diktatorja; neol. na sliki dela že tri leta sliko ima $v$ delu; neol. stol, čigar noga; stvarstvo, čigar središče. V SSKJ so nato ti primeri obravnavani (1) brez kvalifikatorjev, npr. pri 9. pomenu predloga na: navadno z glagolskim samostalnikom za izražanje namena, s katerim se izvrši dejanje: /.../ delati na to, da se

${ }^{7} \gg$ Paberkovalna metoda je zajela predvsem to, kar je v knjigi redko in opazno. Po tej metodi sta bili pregledani dve tretjini vseh izpisanih del. Metoda gostih izpisov je bila uporabljena zlasti pri klasičnih leposlovnih delih; zajela je ne samo posebno, ampak tudi splošno besedišče, v prvi vrsti frazeologijo. $Z$ metodo popolnih izpisov, po kateri se vsaka beseda izpiše tolikokrat, kolikokrat se v besedilu pojavi, so bila izpisana izbrana temeljna dela (ali njih del) vseh zvrsti knjižnega jezika (30 enot). Tako so bile zajete vse temeljne besede in zveze; razen tega je po teh izpisih mogoče ugotavljati pogostnost rabe pri besedah. Po metodi problemskih izpisov je bilo pregledano manjše število del, da bi se dopolnilo splošno gradivo glede na posamezne slovnične kategorije (npr. primernik, deležniki)« (§ 12). 
načrt uresniči; (2) s kvalifikatorjem publicistično, ${ }^{8}$ npr. pri 3. pomenu glagola delati: preh., s širokim pomenskim obsegom $z$ delom omogočati nastajanje česa: /.../ publ. dela na slovarju sestavlja, dela ga; (3) s kvalifikatorjem neustaljeno, ${ }^{9}$ npr. pri zaimku čigar: neustalj. izraža pripadnost stvarnemu ali pojmovnemu imenu moškega ali srednjega spola; katerega: kostanj, čigar senca ga je prikrivala; stvarstvo, čigar središče je luč.

$\mathrm{S}$ tematiko leksike določenega obdobja, ki je bila $\mathrm{v}$ jezik sprejeta $\mathrm{v}$ znanem času, lahko povežemo Dodatek v peti knjigi SSKJ (T-Ž, 1991) z gesli A-ك̌, ki so nastala po izidu posameznega zvezka. Novih gesel je glede na čas, ki naj bi ga zajela (približno dvajset let), sorazmerno malo, saj so vsa zbrana na zgolj 20 straneh (1031-1051): »Dodatkov je manj, kot je bilo predvideno; izkazalo se je, da je prišlo v knjižni jezik v dveh desetletjih zlasti veliko strokovnega izrazja, ki je večinoma preveč specialno za splošni slovar. Po drugi strani se je v kartoteki nabralo precej individualnih besednih tvorb, ki po splošno veljavnih pravilih ne morejo biti sprejete v razlagalni slovar srednjega obsega. Pri izboru smo si prizadevali obdržati nespremenjena pravila, da ne bi prišlo do prevelikega razhajanja med začetkom in koncem slovarja« (Jakopin 1991: 1055).

Iz pojasnila lahko ugotovimo, da so se avtorji zavedali težav pri uvrščanju novejše leksike v slovar in da so bili njihovi pomisleki povezani z vključevanjem okazionalizmov (oz. individualnih besednih tvorb, kot jih imenuje Jakopin) in z vprašanjem, kdaj leksem ni več del samo strokovnega izrazja, ampak že splošnega jezika.

Če pogledamo izbor gesel, lahko ugotovimo, katera področja so v dveh desetletjih postala aktualna. V splošni slovar je bilo sprejeto izvorno strokovno izrazje, npr. aids, besediloslovje, eku, kulturologija, printer, pidgin, softver, ki zajema področja medicine, jezikoslovja, bančništva in računalništva. Ostala gesla bi lahko uvrstili na področje družbene ureditve in politike, npr. demosovec, fundamentalizem, fojba, gulag, hiperinflacija, ekologije, npr. biomasa, neosvinčen, prostega časa in športa, npr. aerobika, bowling, disko, fotofiniš, drugih tehničnih sprememb, npr. poimenovanje novih aparatov, tehnologij - fotokopirati, friteza, in sprememb v družini, npr. gospodinjec 'moški, ki opravlja ali vodi domača, hišna dela'. ${ }^{10}$

Gesla, ki so bila obravnavana v Dodatku k peti knjigi SSKJ, so bila v kasnejših izdajah dodana abecednemu seznamu in niso posebej zaznamovana kot novejša leksika. ${ }^{11}$

Posebnega kvalifikatorja za označevanje novejše leksike SSKJ torej nima, nekaj podatkov o časovni pripadnosti gesel pa lahko dobimo s pomočjo časovno-frekvenčnih kvalifikatorjev raba narašča, raba peša, redko, starinsko in zastarelo, od katerih na novejšo

${ }^{8} \S 135$ Beseda, pomen ali zveza, značilna za dnevni in revialni tisk ter za druge oblike javnega sporočanja (branilec, datirati, eskalacija).

${ }^{9} § 157$ Beseda, pomen ali zveza, ki se kljub dosedanjim prepovedim dosti uporablja (bogat, čigar).

${ }^{10}$ Geslo ima kvalifikator šaljivo, ki ima pomen »šaljiva, šegava beseda, pomen ali zveza (bučman, čebula)« (SSKJ, § 149).

${ }^{11} \mathrm{Npr}$. bankomát -a m (â) avtomatska elektronska naprava, s pomočjo katere imetnik posebne kartice sam dviguje gotovino z bančnega računa in opravlja nekatere druge denarne posle. 
leksiko kaže kvalifikator raba narašča, ki je definiran kot »/b/eseda, pomen ali zveza, katere raba se očitno širi« (§151).

Iskanje gesel s kvalifikatorjem raba narašča $\mathrm{v}$ enem izmed pomenov nam da 16 zadetkov: dejavnik, izgin, ker, ki, ljubitelj, ljubiteljstvo, naravnanost, naravnati, neogiben, neogibnost, nevpadljiv, on, sklep, sklepen, vpadljiv, vpadljivost, med njimi pa ni gesel za poimenovanje novih pojmov. Pregled knjig SSKJ pokaže, da je v novejših manj gesel s tem kvalifikatorjem, in sicer jih je »v prvih treh knjigah 12, v 4. knjigi 2 (sklep in sklepen), v 5. knjigi prav tako samo 2 (vpadljiv in vpadljivost) /.../. Te številke kažejo na razvoj gledanja na jezikovno gradivo pri sestavljavcih slovarja v letih nastajanja vseh petih knjig in na to, kako težko je prav oceniti stanje ali stilno vrednost kake pomenske enote. Za nazaj je lažje, za naprej pa je zelo tvegano napovedovati, kam bo šel razvoj. Konkurenčna beseda se pojavi, potem pa se obdrži ali pa tudi ne« (Šircelj Žnidaršič 1993: 403-404). V analizi avtorica sklene, da »se je pokazalo, da oznaka raba narašča nima prave osnove in za enozvezkovni slovar ni priporočljiva« (prav tam: 405). Leta 1994 je izšel ponatis SSKJ v eni knjigi, kvalifikator raba narašča pa je ostal, saj slovarja po letu 1991 niso več spreminjali, tako da je bil kvalifikator izločen šele iz druge izdaje Slovarja slovenskega knjižnega jezika.

\subsubsection{Slovar Slovenskega pravopisa (SSP)}

SSP je izšel leta 2001, izid pa je bil pospremljen z velikimi pričakovanji tudi v zvezi z novim gradivom, ki naj bi ga prinesel. »Novih iztočnic in podiztočnic ima približno $30 \%$. To so predvsem lastna imena, novo občnoimensko izrazje raznih strok (od glasbe do računalništva in botanike /.../), samostojno predstavljeni besedotvorni morfemi (predpone, pripone, deli zloženk in krajšave)« (Dular 2003: 124).

Izidu slovarja je sledilo veliko kritik, povezanih tudi z novejšo leksiko, gradivnimi viri in rabo oznak: »Za take vrste normativni priročnik je seveda potrebno živo sodobno gradivo, ki odseva v veliki meri nov pojmovni svet (predvsem knjižne) slovenščine zadnjih desetih let, ko je tudi formalno postala funkcijsko enaka drugim državnim jezikom; hkrati gre seveda še za jezikovni izraz spreminjanja družbenih in političnih načel, vrednostnih sistemov družbe, za izraz časa, ko se zdi, da se izgublja jezikovna zmožnost (kompetenca) slovenskih govorcev vsaj za (nekatera) področja znanosti /.../. Kljub temu, da je ustrezno gradivo za kritično razčlenitev aktualnega (knjižnega) jezika v relevantnih računalniških besedilnih zbirkah tako rekoč na dosegu roke, se nam ponuja $v$ glavnem 'popravljen' SSKJ in brušena slovenščina iz srede 20. stoletja« (Vidovič Muha 2003: 117-118).

SSP prinaša tudi nove oznake, med katerimi je z vidika obravnave novejše leksike zanimiva novota, ki je definirana kot »jezikovna prvina, katere novost še čutimo; ob njej je lahko kako pojasnilo ali ustreznica: slédje -a s ... nov.; narečjeslôvje -a $\mathrm{s}$ ... nov.; potrésnik -a m ... nov. potresni oškodovanec; utvaríniti -im dov. ... nov. tematizirati« (SP § 1064). Ob definiciji se A. Vidovič Muha (2003: 120, op. 6) sprašuje: »Kdo (naj čuti novost, op. S. Š.), če je že ne preverjamo z aktualnim gradivom? 
Uporabnik nekako s srednješolsko izobrazbo, ki mu je SP namenjen, naj bi 'čutil' 'novoto' terminologije znanstvenega področja?«

Preverjanje gesel z oznako novota je pokazalo, da so od skupno 22 gesel štiri obravnavana v SSKJ (bankomat, gospodinjec, narečjeslovje in bogovladje ${ }^{12}$ ), gesla bogovladje, pesjar, pojunačen, psičkar, psičkarski pa so v korpusu Gigafida (GF) brez pojavitev.

\subsubsection{Slovar slovenskega knjižnega jezika, 2., dopolnjena in deloma prenovljena izdaja (SSKJ-2)}

SSKJ-2 je izšel oktobra 2014, dopolnitev pa zajema gradivne vire in označevanje s kvalifikatorji. Gradivni viri iz SSKJ (§ 11) so dopolnjeni z naslednjo navedbo (SSKJ$2, \S 12)$ : »Gradivni viri za dopolnitve, ki jih prinaša druga, dopolnjena in deloma prenovljena izdaja, so bili zlasti besedilni korpusi Nova beseda, Gigafida in Kres. Izbor besedja, prikazanega v slovarju, je nastal glede na pogostnost pojavitev v gradivu.«

Dodani geselski članki v SSKJ-2 niso označeni s posebnimi kvalifikatorji za novejšo leksiko, tako da je struktura vseh geselskih člankov enaka; npr. gluhoslep, tajkun, kondomat, suši, akreditacija (več primerov dodanih gesel na http://www. mladinska.com/sskj/o_drugi_izdaji_sskj, 27. 3. 2015) imajo enako zgradbo kot npr. matevž in motivacija. ${ }^{13}$ Spremembe opazimo pri časovno-frekvenčnih kvalifikatorjih, saj sta od petih v SSKJ (raba narašča, raba peša, redko, starinsko in zastarelo) ohranjena samo dva - starinsko in zastarelo.

\subsubsection{Slovar novejšega besedja slovenskega (knjižnega) jezika (SNB)}

SNB je prvi slovenski slovar, v katerem je zajeta samo novejša leksika. Izšel je leta 2012, pri čemer so avtorji njegov naslov v fazi nastajanja spremenili in iz naslova umaknili pridevnik knjižni. ${ }^{14}$

V primerjavi s splošnimi slovarji slovarji novejše leksike predstavljajo leksiko nekega (ponavadi krajšega) obdobja, kar velja tudi za SNB: »Temeljno načelo pri izdelavi geslovnika je bilo, da zajame zlasti splošno, t. i. dejavno, živo besedje, ki se je v slovenščini pojavilo oz. uveljavilo v približnem časovnem okviru zadnjih dvajsetih let, kar pomeni, da to besedje v Slovarju slovenskega knjižnega jezika ni obravnavano« (Gložančev, Kostanjevec 2006: 90).

${ }^{12}$ V SSKJ ima geslo kvalifikator zastarelo: »Nekoč rabljena beseda, pomen ali zveza; danes je v knjižnem jeziku mrtva (blagajnica, diviti se). O tem, kakšno stilno vrednost je imela tako kvalificirana beseda nekoč, slovar ne daje pojasnil« (SSKJ, § 155).

${ }^{13}$ SSKJ-2: matévž -a m (ệ) gastr., navadno v zvezi belokranjski matevž pretlačen krompir in fižol z ocvirki: kranjska klobasa in belokranjski matevž; súši -ja m (û) gastr. japonska jed iz riža, alg, mesa surove ribe, drugih morskih živali ali zelenjave in začimb: surovo meso morskih živali za suši mora biti popolnoma sveže; restavracija s sušijem, v kateri strežejo suši / japonski suši.

${ }^{14}$ Leta 2003 ima članek N. Holz v naslovu Slovar novejšega besedja slovenskega knjižnega jezika. 
Če zasnovo primerjamo z nemškim slovarjem, ugotovimo, da so si Nemci za obravnavo izbrali krajše časovno obdobje - 10 let (Herberg 2003: 27). Za krajše obdobje so se v dveh slovarjih neologizmov odločili tudi Čehi; prvi slovar zajema obdobje 1985-1995 (Martincova 1998), drugi 1996-2002 (Martincova 2004).

Odločitev za daljše obdobje je povezana s tem, da naj bi bil slovar »namenjen zlasti pripravi novega splošnega razlagalnega slovarja v smislu dopolnila Slovarju slovenskega knjižnega jezika (SSKJ)« (Gložančev, Kostanjevec 2006: 89), torej SNB ni slovar novejše leksike $\mathrm{z}$ »množico dodatnih podatkov, kot je izvor posameznih novih besed, če je mogoče, čas, včasih tudi točen datum, ko so se pojavile, podatek o tem, kdo jih je prvi uporabil, potem ortografske in/ali morfološke variante (če gre za sposojenke), slovnične posebnosti itd.« (Muhvić-Dimanovski 2005: 81).

Priprava geslovnika naj bi potekala tudi s pomočjo korpusov, članki pa kažejo na to, da se je koncept slovarja spreminjal. V članku N. Holz (2003: 90) preberemo, da je

»/p/riprava geslovnika /.../ eden od temeljev za sestavo slovarja, pri čemer je nujna uporaba sodobnih sredstev, konkretno jezikovnih korpusov (poleg tega so potrebni še konkordančniki za obdelavo korpusnih podatkov - seveda pa tudi dovolj zmogljiva računalniška oprema ter zadostno jezikoslovno in računalniško znanje za smiselno uporabo vsega naštetega). Korpusa FIDA in Nova beseda sta različno zasnovana, zato bi bilo pri sestavljanju geslovnika za SNB zelo koristno kombinirati informacije iz obeh; ker pa dogovori za uporabo korpusa FIDA še potekajo, je bil v tem času za pripravo geslovnika na voljo le korpus Nova beseda.«

V članku o korpusu Nova beseda in geslovniku preberemo tudi, da so bili »/z/a potrebe geslovnika SNB /.../v aprilu 2003 pripravljeni spiski nelematiziranega besedja iz korpusa Nova beseda za črke A-K, in sicer ob predpostavki, da bo med nelematiziranim besedjem mogoče najti glede na SSKJ nove besede za vključitev v geslovnik $\mathrm{SNB} \ll$ (prav tam).

Drugače je zbiranje gradiva opisano v članku o načrtovanem slovarju novejšega besedja slovenskega jezika (Bokal idr. 2003: 14):

»Prvi elektronski vir za novo besedje so računalniško vnesena gesla, izpisana iz izbrane literature ${ }^{15} / . . . /$; drugi vir za izbiranje novega besedja je računalniško pripravljen Seznam z malo začetnico pisanih iztočnic in podiztočnic iz Slovenskega pravopisa, ki jih ni v SSKJ (interno gradivo).

Listkovno gradivo iz nove kartoteke in zgoraj omenjena elektronska vira primerjamo z inštitutsko besedilno zbirko Nova beseda. Tako bomo dobili podatek o razširjenosti besede, dodatno bomo iskali pogoste splošne in terminološke besede, ki jih bo treba sprejeti

${ }^{15}$ Gre za dve kartoteki. »Gradivo za prvo je bilo izbrano in urejevano za izdelavo SSKJ; izpisano je bilo iz okoli šest tisoč tiskanih enot, katerih večina je iz druge polovice dvajsetega stoletja, nekatere tudi iz zadnje tretjine devetnajstega stoletja (klasiki). /.../ Druga kartoteka, ki predstavlja edino klasično listkovno gradivno zbirko v Leksikološki sekciji, nastaja od izida 5. knjige SSKJ, tj. od leta 1991. Služila je že kot pomemben vir za izdelavo geslovnika za SP 2001, zdaj pa je namenjena za izdelavo različnih drugih pripravljajočih se slovarjev v Leksikološki sekciji. V tej drugi, t. i. novi kartoteki je nekaj več kot 140.000 besed« (Bokal idr. 2003: 13). 
v SNB, v listkovnem gradivu pa zaradi priložnostnega načina izpisovanja niso zajete, predvsem v Novi besedi. Tudi novih besed iz SP 2001 ne bomo navajali brez preverjanja po elektronskih zbirkah. S pregledovanjem zvrstno, funkcijsko in stilno različnih besedil želimo pretresti knjižni jezik in vključiti v SNB v zadnjem času uporabljano besedje, ker bomo le tako lahko opisali normo knjižnega jezika.

Pri novem besedju iščemo podatke o splošni poznanosti in pogostosti predvsem v elektronskih besedilnih zbirkah, ker za listkovno kartoteko popolnih izpisov zaradi premalo izpisovalcev ne delamo. $\mathrm{V}$ dvomnih primerih pregledujemo domače splošne in področne slovarje, leksikone in tuje slovarje.«

Temeljna razlika med obema konceptoma je v tem, da prvi (Holz 2003) izhaja iz korpusa Nova beseda, ki naj bi bil vir za nova gesla, drugi (Bokal idr. 2003) pa daje prednost drugim virom (kartoteka, računalniško pripravljen Seznam z malo začetnico pisanih iztočnic in podiztočnic iz Slovenskega pravopisa, ki jih ni v SSKJ), tudi slovarjem, leksikonom, enciklopedijam, ${ }^{16}$ elektronske besedilne zbirke, zlasti Nova beseda, pa naj bi bile uporabljene samo kot »/p/otrditev o razširjenosti določene besede« (Bokal idr. 2003: 15).

Kasneje je bil načrt zbiranja gradiva še dopolnjen in tri leta kasneje lahko preberemo (Gložančev, Kostanjevec 2006: 95):

»Temeljni izhodiščni vir za pripravo geslovnika tako predstavlja klasična Listkovna kartoteka (po letu 1991 v Leksikološki sekciji zbranega besedja), temeljni referenčni vir pa elektronski besedilni korpus Nova beseda /.../. Kot dodatni vir so pomembni t. i. priložnostni izpisi novejšega besedja (ki so jih načeloma prispevali sodelavci skupine pri projektu SNB), t. i. mala elektronska zbirka, ki nastaja v Leksikološki sekciji v okviru projekta SNB (od klasičnega listkovnega gradiva se razlikuje pač po elektronski obliki zapisa in dostopa), pa tudi elektronski pregledovalniki (npr. Najdi.si, Google). Kot dodatni konsultacijski viri so bili uporabljeni tudi tuji slovarji novega besedja.«

Kasneje je bil geslovnik še dopolnjen in v Uvodu v SNB (Bizjak Končar 2012: 9) je pojasnjeno, da so se »/p/ri sestavi geslovnika /.../ oprli na zbirko novejšega besedja, ki je nastala v okviru projekta Novejša slovenska leksika (v povezavi s spletnimi jezikovnimi viri). / .../ Najpomembnejše pa je, da je bil za pripravo zbirke novejšega besedja kot temeljni gradivni vir uporabljen besedilni korpus Nova beseda /.../. Ta korpusno zgrajeni geslovnik je bil primerno izhodišče za slovarsko obravnavo, ki korpusno orientacijo v veliki meri razširja na slovarsko besedilo.«

SNB tako prinaša novejšo eno- ali večbesedno leksiko na izrazni ravni (tajkun, mlekomat; etnično čiščenje), novopomenke (klon, knjigar; balkanske vojne). Na povezavo s SSKJ kaže grafično znamenje SSKJ, ki ga najdemo ob novopomenkah ali novih večbesednih leksemih, katerih del je že obravnavan v SSKJ.

${ }^{16} \gg$ Iz slovarjev, leksikonov in enciklopedij bomo zbirali besedje za pravo, medicino, biologijo, okolje, računalništvo, šport, skratka za področja, za katera se zanima veliko ljudi. Iz časopisov in revij bomo zbirali zlasti publicistične izraze« (Bokal idr. 2003: 15). 


\subsubsection{Novejša leksika na spletnem portalu www.slovenscina.eu}

Na spletnem portalu www.slovenscina.eu najdemo informacije o novejši leksiki, ki so bile zbrane na podlagi korpusov, in sicer v okviru projekta Sporazumevanje v slovenskem jeziku od leta 2008 do 2013.

Novejšo leksiko obravnava Sloleks, »/l/eksikon besednih oblik za slovenski jezik«, ki »vsebuje osnovne podatke o slovenskih besedah, predvsem v katero besedno vrsto spadajo in kakšne so njihove lastnosti. Pri vsaki besedi so v bazi zabeležene tudi vse njene pregibne oblike «. ${ }^{17}$ Trenutno vsebuje več kot 100.000 besed oz. lem, med njimi tudi novejšo leksiko, npr. suši, ${ }^{18}$ akreditacija, pajkice, DVD. Ker gre za leksikon oblik, novejša leksika ni posebej označena, obravnavane so samo enobesedne enote, med njimi pa so tudi lastna imena.

V zavihku Spletni slovar se nam odpre Leksikalna baza za slovenščino (LBS), ki »predstavlja izčrpen pomenski in skladenjski opis izbranega nabora slovenskih besed, ki je izdelan izključno na podlagi analize referenčnih besedilnih korpusov «. ${ }^{19}$ »Izbor besed v leksikalni bazi temelji na geslovniku 5.000 najpogostejših besed v korpusih FidaPLUS in Gigafida, upoštevali pa smo tudi izbor besed iz osnovno- in srednješolskih učbenikov, da bi se čim bolj približali realnim problemom šolarjev in dijakov.« Doslej obravnavana gesla najdemo v Spletnem slovarju slovenskega jezika (testni spletni prikaz gesel leksikalne baze za slovenščino) z novejšimi leksemi kot npr. deaktivirati, ebola, piercing. Leksikalna baza vsebuje samo predmetnopomenske besede, novejša leksika pa ni posebej označena. Iščemo lahko samo enobesedna gesla, v posebnem zavihku »stalne zveze« pa so zbrana tudi večbesedna gesla, pri geslu greda npr. topla greda VRTNARSTVO, gramozna greda OBLIKOVANJE KRAJINE, gramozna greda in topla greda EKOLOGIJA.

Na podlagi opisa leksikalnih enot v LBS »naj bi bilo mogoče izdelati različne končne opise /.../, pri čemer je mogoče izpostaviti zlasti splošni enojezični in šolski slovar, slovar za učenje slovenščine kot tujega jezika, dvojezične slovarje in priročnike, ki se osredotočajo samo na določen tip leksikalno-slovničnih podatkov /.../. V tem smislu je LBS namenjena predvsem leksikografom in jezikovnim analitikom ter še ne predstavlja končnega izdelka« (Gantar 2011: 77-78).

${ }^{17} \mathrm{Gl}$. http://www.slovenscina.eu/sloleks/opis (22. 5. 2015).

${ }^{18}$ Delo s Sloleksom poteka tako, da v iskalno polje vpišemo besedo, npr. suši, nato pa nam v našem primeru ponudi štiri možnosti (suša samostalnik, občno ime, ženski spol; Suša samostalnik, lastno ime, ženski spol; suši samostalnik, občno ime, moški spol in sušiti glagol, nedovršni). Po izbiri samostalnika moškega spola Sloleks izpiše število pojavitev v korpusu GF in sklanjatveni vzorec, ki pa ima v primeru sušija $\mathrm{v}$ tožilniku ednine napako, saj je primer ješ suši lematiziran kot »suša samostalnik, občno ime; ženski spol, ednina, mestnik«. Zaradi napačne lematizacije dobimo podatek, da ima suši v tožilniku ednine pogostost nič.

${ }^{19} \mathrm{Gl}$. http://www.slovenscina.eu/spletni-slovar/leksikalna-baza (22. 5. 2015). 


\section{Bibliografija}

Bajec, Anton idr. (ur.). 1964. Slovar slovenskega knjižnega jezika: poskusni snopič. Ljubljana: Slovenska akademija znanosti in umetnosti.

Bizjak Končar, Aleksandra. 2012. Uvod. Slovar novejšega besedja slovenskega jezika: 9-11.

Bokal, Ljudmila, Gložančev, Alenka, Jakop, Nataša, Kostanjevec, Polona in Vojnovič, Nastja. 2003. O načrtovanem slovarju novejšega besedja slovenskega jezika. Jezikoslovni zapiski 9/1: 7-47.

Debenjak, Doris, Božidar in Primož. 1994. Nemško-slovenski slovar. Elektronska izdaja. Ljubljana: DZS.

Duden. Deutsches Universalwörterbuch A-Z. 1997. Elektronska izdaja. Mannheim: Bibliographisches Institut \& F. A. Brockhaus AG.

Duden. Deutsches Universalwörterbuch. 2007. 6., überarbeitete Auflage. Mannheim, Leipzig, Wien, Zürich: Dudenverlag.

Duden. Die deutsche Rechtschreibung. 2009. 25., völlig neu bearbeitete und erweiterte Auflage. Mannheim: Dudenverlag.

Dular, Janez. 2003. Pravopisni kompromis ali kompromisni pravopis. SR 51/2. 123-126.

Gantar, Polona. 2011. Leksikalna baza za slovenščino: komu, zakaj in kako (naprej)? Jezikoslovni zapiski 17/2: 77-92.

Gložančev, Alenka in Kostanjevec, Polona, 2006. Novejše besedje slovenskega knjižnega jezika - seznam (A-O). Jezikoslovni zapiski 12/2. 89-159.

Gložančev, Alenka, Jakopin, Primož, Michelizza, Mija, Uršič, Urška, Žele, Andreja. 2009. Novejša slovenska leksika: v povezavi s spletnimi jezikovnimi viri. Ljubljana: Založba ZRC, ZRC SAZU.

Gstöttner, Maria. 2003. Neologismen in der deutschen Gegenwartssprache. Wien: GRIN Verlag.

Herberg, Dieter. 2002. Neologismen in der deutschen Gegenwartssprache. Probleme ihrer Erfassung und Beschreibung. Deutsch als Fremdsprache 4/2002: 195-200.

Herberg, Dieter. 2003. Neologismen in der deutschen Gegenwartssprache. Forum Deutsch 11: 27-31. Montreal/Kanada.

Herberg, Dieter, Kinne, Michael, Steffens, Doris in Tellenbach, Elke. 2004. Neuer Wortschatz: Neologismen der 90er Jahre im Deutschen. Berlin, New York: Walter de Gruyter, Schriften des Instituts für Deutsche Sprache. E-vir: http://hypermedia.ids-mannheim.de/pls/elexiko/ p4 module.woerterbuch (1. 10. 2008).

Holz, Nanika. 2003. Besedilni korpus Nova beseda in geslovnik za Slovar novejšega besedja slovenskega knjižnega jezika. Jezikoslovni zapiski 9/1. 89-94.

Humar, Marjeta. 2004. Stanje in vloga slovenske terminologije in terminografije. Terminologija $v$ času globalizacije. Ur. Marjeta HumAR. Ljubljana: Založba ZRC SAZU. 17-31.

Jakopin, Franc. 1991. Sklepna beseda. Slovar slovenskega knjižnega jezika, 5. knjiga. 1055.

Kinne, Michael. 1996. Neologismen und Neologismenlexikographie im Deutschen. Deutsche Sprache 24/4: 327-358.

Kirkness, Alan. 2001. Europäismen/Internationalismen im heutigen deutschen Wortschatz. Eine lexikographische Pilotstudie. V: G. STickel (ur.), Neues und Fremdes im deutschen Wortschatz: aktueller lexikalischer Wandel. Berlin, New York: de Gruyter. (Institut für Deutsche Sprache, Jahrbuch 2000). 105-130.

Klappenbach, Ruth, Steinitz, Wolfgang (ur.). 1967 (1964). Wörterbuch der deutschen Gegenwartssprache. 1. Band. Berlin: Akademie-Verlag. http://www.dwds.de/ (1. 7. 2008, 27. 3. 2015). 
Korpus Gigafida, <www.gigafida.net> (27. 3. 2015).

Martincová, Olga. 1998. Nová slova v češtině: slovník neologizmů. Praha: Akademia.

Martincová, Olga. 2004: Nová slova v češtině 2: slovník neologizmů. Praha: Akademia.

Muhvić-Dimanovski, Vesna. 2005: Neologizmi: problemi teorije i primjene. Zagreb: Filozofski fakultet, Zavod za lingvistiku.

OWID, Online-Wortschatz-Informationssystem Deutsch des Instituts für deutsche Sprache, Mannheim, <http://www.owid.de/> (13. 3. 2008).

Pogorelec, Breda. 1963/64. O poskusnem snopiču Slovarja slovenskega knjižnega jezika. JiS 9/7-8: 232-242.

Popović, Milenko. 1967: R. A. Bugadov: Neologizmi i arhaizmi. Pokušaj njihove klasifikacije. Suvremena lingvistika 2/4: 233-237.

Schippan, Thea. 2002² (1992): Lexikologie der deutschen Gegenwartssprache. Tübingen: Niemeyer.

Slovar slovenskega knjižnega jezika. 1994. Elektronska izdaja na plošči CD-ROM. Ljubljana: SAZU in ZRC SAZU, Inštitut za slovenski jezik Frana Ramovša, DZS, d. d., in Amebis, d. o. o.

Slovar slovenskega knjižnega jezika. 2014. 2., dopolnjena in deloma prenovljena izd., elektronska objava. El. knjiga. Ljubljana: Založba ZRC, Znanstvenoraziskovalni center SAZU.

Slovenski pravopis. 2003. Elektronska izdaja. Ljubljana: ZRC SAZU, Inštitut za slovenski jezik Frana Ramovša in Amebis, d. o. o.

Sporazumevanje v slovenskem jeziku, <www.slovenscina.eu> (22. 5. 2015).

Šircelj Žnidaršič, Ivanka. 1993. Oznaki »raba peša« in »raba narašča« v Slovarju slovenskega knjižnega jezika, zlasti z ozirom na novonastajajoči enozvezkovni slovar. Jezik tako in drugače: $401-409$.

Štumberger, Saška. 2011. Pojmovni svet in struktura novejše slovenske leksike. Doktorska disertacija. Ljubljana.

Štumberger, Saška. 2014. Obravnava jezikovnih novosti v nemškem slovaropisju. Posvet o novem slovarju slovenskega jezika, Ministrstvo za kulturo 12. 2. 2014. Ljubljana.

Toporišič, Jože. 1992. Enciklopedija slovenskega jezika. Ljubljana: Cankarjeva založba.

Vidovič Muha, Ada. 1972. Kategorizacija in stilna opredelitev ozko knjižne leksike. VIII. seminar slovenskega jezika, literature in kulture: $35-52$.

Vidovič Muha, Ada. 2000. Slovensko leksikalno pomenoslovje: govorica slovarja. Ljubljana: Znanstveni inštitut Filozofske fakultete.

Vidovič Muha, Ada. 2003. Kaj je novega v knjižnem jeziku? - Ob izidu Slovenskega pravopisa. SR 51/2: 117-122.

Prispelo aprila 2015, sprejeto maja 2015

Received April 2015, accepted May 2015 


\section{Slovaropisna obravnava novejše leksike}

V prispevku je predstavljena slovaropisna obravnava novejše leksike, ki zajema splošne slovarje in posebne slovarje novejše leksike. V splošnih slovarjih je bil v poskusnem snopiču Slovarja slovenskega knjižnega jezika (SSKJ) načrtovan poseben kvalifikator za novejšo leksiko, ki pa je bil kasneje opuščen. Novejša leksika nima posebnih kvalifikatorjev niti v drugi izdaji SSKJ, čeprav je bila druga izdaja oglaševana $\mathrm{s}$ poudarjanjem vključitve novejšega besedja zadnjih desetletij. Praksa neoznačevanja v splošnih slovarjih se kaže tudi v nemškem slovaropisju, kjer z izjemo vzhodnonemškega slovarja Wörterbuch der deutschen Gegenwartsprache (1967) novejše leksike ravno tako ne označujejo s posebnimi časovnimi kvalifikatorji.

Posebni slovarji novejše leksike praviloma zajemajo leksiko določenega obdobja, npr. Slovar novejšega besedja slovenskega jezika (2012) z obravnavo leksike dveh desetletij kot dopolnilno nadaljevanje SSKJ. Druge vrste so slovarji novejše leksike, ki so izdani šele po vključitvi leksike v splošne slovarje, npr. Neuer Wortschatz: Neologismen der 90er Jahre im Deutschen (2004). V tem primeru namen slovarja ni dopolnilo obstoječih slovarjev, ampak bolj natančna predstavitev izbrane leksike določenega obdobja.

\section{Lexicographic handling of new lexis}

The article presents lexicographic handling of new lexis including both general dictionaries and specialized dictionaries of new lexis. Regarding general dictionaries, for the test version of the Dictionary of the Standard Slovenian Language (DSSL) a special qualifier for new lexis was planned but was dropped later. New lexis is also not labelled with a special qualifier in the second edition of the DSSL, even though the second edition was advertised as a dictionary that contains new lexis of the last few decades. The practis of non-labelling in general dictionaries is reflected also in German lexicography in which, with the exception of the East German dictionary Wörterbuch der deutschen Gegenwartsprache (1967), new lexis is also not labelled with special time qualifiers.

As a rule, specialized dictionaries of new lexis contain lexis of a certain period, e.g., Dictionary of New Words of the Slovenian Language (2012), including the lexis of the last two decades as a supplemental follow-up to the DSSL. Dictionaries of new lexis that are published after the new lexis has been included in general dictionaries are different in this regard, e.g., Neuer Wortschatz: Neologismen der 90er Jahre im Deutschen (2004). In this case, the aim of the dictionary is not to supplement the existing dictionaries but to present the selected lexis of a certain period more thoroughly. 